\title{
Three new supramolecular networks formed via hydrogen bonding interactions: Syntheses, crystal structures and magnetic properties
}

\author{
Jian-Qiang Liu ${ }^{\text {a }, \text { Yao-Yu Wang }}{ }^{\text {a,*, }}$ Lu-Fang Ma ${ }^{\text {a }}$, Wei-Hong Zhang ${ }^{a}$, Xi-Rui Zeng ${ }^{b}$, \\ Fan Zhong ${ }^{\mathrm{a}, \mathrm{b}}$, Qi-Zhen Shi ${ }^{\mathrm{a}}$, Shie-Ming Peng ${ }^{\mathrm{c}}$ \\ ${ }^{a}$ Department of Chemistry/Shaanxi Key Laboratory of Physico-inorganic Chemistry, Northwest University, Xi'an 710069, PR China \\ ${ }^{\mathrm{b}}$ Department of Chemistry, Jinggangshan College, Ji'an 343009, PR China \\ ${ }^{\mathrm{c}}$ Department of Chemistry, National Taiwan University, Taipei, Taiwan
}

Received 29 June 2007; accepted 29 June 2007

Available online 17 July 2007

\begin{abstract}
Three new iron(III) citrate complexes $\left[\mathrm{Fe}_{2}(\mathrm{cit})_{2}\left(\mathrm{H}_{2} \mathrm{O}\right)_{2}\right]\left(\mathrm{H}_{2} \mathrm{bpa}\right)(\mathbf{1}),\left[\mathrm{Fe}_{2}(\mathrm{cit})_{2}\left(\mathrm{H}_{2} \mathrm{O}\right)_{2}\right]\left(\mathrm{H}_{2} \mathrm{bpe}\right)(\mathbf{2})$ and $\left[\mathrm{Fe}_{4}(\mathrm{cit})_{4}\left(\mathrm{H}_{2} \mathrm{O}\right)_{4}\right]\left(\mathrm{H}_{2} \mathrm{bpp}\right)_{2}\left(\mathrm{H}_{2} \mathrm{O}\right)$ (3) $\left(\mathrm{cit}=\mathrm{C}\left(\mathrm{O}^{-}\right)\left(\mathrm{COO}^{-}\right)\left(\mathrm{CH}_{2} \mathrm{COO}^{-}\right)_{2}\right.$, bpa $=1,3$-bis(4-pyridyl)ethane, bpe $=1,3$-bis(4-pyridyl)ethene, bpp $=1,3$-bis $(4$-pyridyl)propane $)$ were synthesized and characterized by elemental analysis, spectroscopic techniques and magnetic properties. Single X-ray diffraction analyses in the 1-3 complexes reveal that the iron ion is six-coordinated and is bound by two deprotonated citrates and a pair of aqua ligands in a distorted octahedral fashion. The anionic complex contains a centro-symmetrical planar of four-membered $\mathrm{Fe}_{2} \mathrm{O}_{2}$ ring. There are significant contributions to the stabilities of the assembled lattices in 1-3 arising from the protonated pyridine analogue counterions neutralizing the anionic charges of the complexes. The units in the complexes are connected together via hydrogen bonding to form 3D supramolecular networks. The supramolecular structures of $\mathbf{1}-\mathbf{2}$ show alternating $R_{6}^{6}(50)$ and $R_{6}^{4}(48)$ motif linking the anionic moieties which are in turn interwoven with cationic moieties, while $\mathbf{3}$ shows alternating $R_{6}^{6}(51)$ and $R_{6}^{4}(49)$ motif. The magnetic properties of 1-3 are investigated and discussed in detail.
\end{abstract}

(C) 2007 Published by Elsevier B.V.

Keywords: Iron (III); Citrate; Hydrogen bonds; Supramolecular networks; Magnetic behaviors

\section{Introduction}

The prevalent citric acid has been widely known for its abundance in physiological fluids [1]. They ubiquitously involve in the active sites of bacterial metalloenzyme, including the aconitase iron-sulfur and the nif $\mathrm{V}^{-}$nitrogenase cofactor [2]. Citric acid is also found in human blood plasma at a concentration of $\sim 0.1 \mathrm{mM}$ and is considered to be a preeminent, small molecular weight binder of a number of metals, including iron. The postulate that, upon binding, citric acid enhances the mobilization and bioavail-

\footnotetext{
${ }^{*}$ Corresponding author. Tel./fax: +862988303798.

E-mail address: wyaoyu@nwu.edu.cn (Y.-Y. Wang).
}

ability and promotes absorption of dietary non-heme iron, has also attracted the different groups' interest [3]. Binuclear iron complexes were studied long ago by the pioneers Earnshaw, Lewis and Murray [4]. To day there exist a limited number of structurally characterized polymeric iron (III) and dimeric iron (III)-citrate complexes [5], and there are significant contributions to the stabilities of the assemble lattices in them arising from the counterions neutralizing the high anionic charges of the complexes.

On the other hand, experimental generation of supramolecular aggregates based on $\mathrm{H}$-bonding could be achieved via versatile donor-acceptors interaction and even with free partners (solvents, organic molecules) in the lattice [6]. Increasing the number of the components, polar bridging groups with variable spacer and counterions 
definitely play a crucial role in deciding whether 1D molecular chains are interlocked to form 2D networks which in turn could be cross linked into 3D networks. Therefore, the intricate association of molecular synthons through weak forces results in multidimensional structures. In hydrogen-bonded adducts of simple bis-phenols or tri-carboxylic acid with tertiary dimines, the primary mode of supramolecular aggregation is chain formation by hard $\mathrm{O}-\mathrm{H} \cdots \mathrm{N}$ and/or $\mathrm{O}-\mathrm{H} \cdots \mathrm{O}$ hydrogen bonds [6e,6f,6g]. Hydroxypolycarboxylic acids can act not only as hydrogen-bond acceptors but also as hydrogen-bond donors, depending on the number of deprotonated carboxyl group. In principle, it can provide abundantly intermolecular hydrogen-bonding and intermolecular hydrogen-bonding to construct more intricate supramolecular network. There are a number of structures reports on salts of citric acid with organic bases, and with anionic metal-coordination complexes [5], rather few investigations are studied the role in iron(III) with citrate supramolecular chemistry. In this study, the rational construction of bis-tertiary amines attempts to constrain the acid-base interactions to chainformation only, in order to render the resulting supramolecular structures as simple as possible. We also focus efforts on their magnetic properties in order to study the magnetic coupling between two ions and to establish magneto-structural correlations. Magnetic data indicate that exoteric cations that hardly attributed to anti-ferromagnetic exchange interaction between the two Fe (III) centers.

\section{Experimental}

\subsection{Materials and physical measurements}

All the reagents, including the bpa, bpe and bpp were purchased from commercial sources and used as received.
FT-IR spectra ( $\mathrm{KBr}$ pellets) were taken on a FT-IR 170SX (Nicolet) spectrometer and electronic absorption spectra with a Hitachi UV-3010 spectrophotometer. Elemental analyses were performed on a Perkin-Elmer 240C analyzer. The magnetic susceptibility of microcrystalline sample restrained in parafilm was measured on an Oxford Maglab 2000 magnetometer with an applied field of $1 \mathrm{kOe}$. Diamagnetic correction was estimated from Pascal's constants [7].

\subsection{Synthesis of $\left[\mathrm{Fe}_{2}(\mathrm{cit})_{2}\left(\mathrm{H}_{2} \mathrm{O}\right)_{2}\right]\left(\mathrm{H}_{2} \mathrm{bpa}\right)$ (1)}

Compound 1 was synthesized hydrothermally from the reaction of ferric nitrate $(0.484 \mathrm{~g}, 2 \mathrm{mmol})$, sodium citrate $(0.243 \mathrm{~g}, 1 \mathrm{mmol})$, bpa $(0.184 \mathrm{~g}, 1 \mathrm{mmol})$ and water $(10 \mathrm{~mL})$. The mixture was sealed at $150^{\circ} \mathrm{C}$ for 7 days then cooled at a rate of about $3.5^{\circ} \mathrm{C} \mathrm{h}^{-1}$. Yellow block of $\mathbf{1}$ for $\mathrm{X}$-ray diffraction study and other measurements were manually collected under a microscope. Anal. Calc. for $\mathrm{C}_{24} \mathrm{H}_{26} \mathrm{Fe}_{2} \mathrm{~N}_{2} \mathrm{O}_{16}$ (1): C, 40.59; H, 3.69; N, 3.94. Found: $\mathrm{C}, 40.89 ; \mathrm{H}, 3.50 ; \mathrm{N}, 4.02 \%$. IR $\left(\mathrm{KBr} \mathrm{cm}^{-1}\right): 3094(\mathrm{~s})$, 2916(w), 2154(s), 1629(v), 1500(s), 1358(v), 1237(v), 1085(v), 842(v), 640(v).

\section{3. $\left[\mathrm{Fe}_{2}(\mathrm{cit})_{2}\left(\mathrm{H}_{2} \mathrm{O}\right)_{2}\right]\left(\mathrm{H}_{2} \mathrm{bpe}\right)$ (2)}

Compound 2 was synthesized under the same condition and ratio except for the bpe $(0.182 \mathrm{~g}, 1 \mathrm{mmol})$ instead of bpa. Yellow block of $\mathbf{2}$ for X-ray diffraction study and other measurements were manually collected under a microscope. Anal. Calc. for $\mathrm{C}_{24} \mathrm{H}_{24} \mathrm{Fe}_{2} \mathrm{~N}_{2} \mathrm{O}_{16}$ (2): C, 40.71; H, 3.96; N, 3.96. Found: C, 40.19; H, 3.55; N, $3.88 \%$. IR $\left(\mathrm{KBr} \mathrm{cm}^{-1}\right): \quad 3097(\mathrm{~s}), \quad 2338(\mathrm{~m}), \quad 1628(\mathrm{v})$, 1501(s), 1369(v), 1242(v), 1087(v), 842(v), 644(v).

Table 1

Crystal data and structure refinement information for compound 1-3

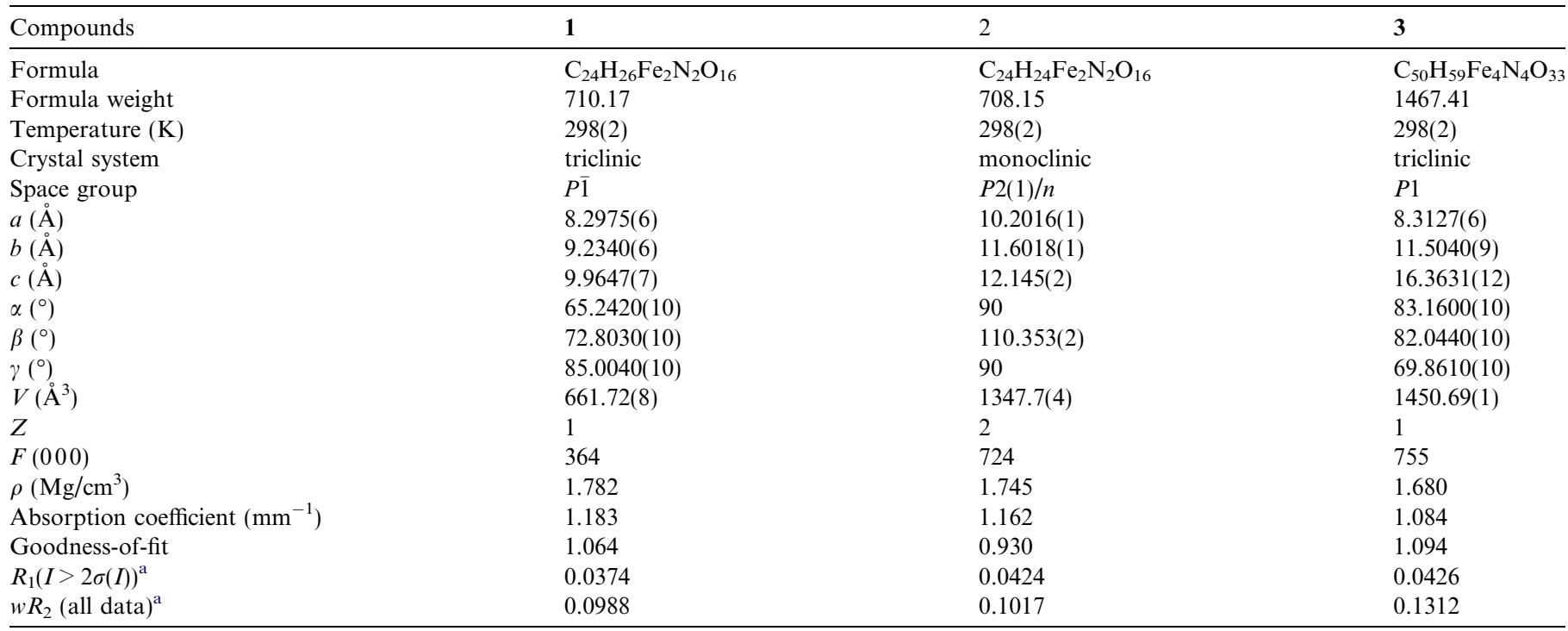

${ }^{\mathrm{a}} R_{1}=\sum|| F_{\mathrm{o}}|-| F_{\mathrm{c}}|| / \sum\left|F_{\mathrm{o}}\right|, \mathrm{w}_{2}=\left\{\sum\left[\mathrm{w}\left(F_{\mathrm{o}}{ }^{2}-F_{\mathrm{c}}{ }^{2}\right)^{2}\right] / \sum\left(F_{\mathrm{o}}{ }^{2}\right)^{2}\right\}^{1 / 2}$. 
Table 2

Selected bond distances $(\AA)$ and angles $\left(^{\circ}\right)$

\begin{tabular}{|c|c|c|c|}
\hline \multicolumn{4}{|l|}{ Complex 1} \\
\hline $\mathrm{Fe}(1)-\mathrm{O}(2)$ & $1.968(2)$ & $\mathrm{Fe}(1)-\mathrm{O}(8) \# 1$ & $2.00(2)$ \\
\hline $\mathrm{Fe}(1)-\mathrm{O}(4) \# 1$ & $2.025(2)$ & $\mathrm{Fe}(1)-\mathrm{O}(6) \# 1$ & $2.04(2)$ \\
\hline $\mathrm{O}(8) \# 1-\mathrm{Fe}(1)-\mathrm{O}(4)$ & $161.1(8)$ & $\mathrm{O}(2)-\mathrm{Fe}(1)-\mathrm{O}(1 \mathrm{~W})$ & $88.5(9)$ \\
\hline $\mathrm{O}(8) \# 1-\mathrm{Fe}(1)-\mathrm{O}(1 \mathrm{~W})$ & $93.5(1)$ & $\mathrm{O}(4)-\mathrm{Fe}(1)-\mathrm{O}(1 \mathrm{~W})$ & $105.3(1)$ \\
\hline $\mathrm{O}(2)-\mathrm{Fe}(1)-\mathrm{O}(4) \# 1$ & $109.4(8)$ & $\mathrm{O}(8) \# 1-\mathrm{Fe}(1)-\mathrm{O}(4) \# 1$ & $85.0(8)$ \\
\hline $\mathrm{O}(4)-\mathrm{Fe}(1)-\mathrm{O}(6) \# 1$ & $94.4(8)$ & $\mathrm{O}(1 \mathrm{~W})-\mathrm{Fe}(1)-\mathrm{O}(6) \# 1$ & $82.7(9)$ \\
\hline $\mathrm{O}(4) \# 1-\mathrm{Fe}(1)-\mathrm{O}(6) \# 1$ & $79.4(8)$ & & \\
\hline \multicolumn{4}{|l|}{ Complex $\mathbf{2}$} \\
\hline $\mathrm{Fe}(1)-\mathrm{O}(7) \# 2$ & $1.972(3)$ & $\mathrm{Fe}(1)-\mathrm{O}(6) \# 2$ & $1.99(2)$ \\
\hline $\mathrm{Fe}(1)-\mathrm{O}(2)$ & $1.997(3)$ & $\mathrm{Fe}(1)-\mathrm{O}(1 \mathrm{~W})$ & $2.02(3)$ \\
\hline $\mathrm{Fe}(1)-\mathrm{O}(4)$ & $2.028(3)$ & $\mathrm{Fe}(1)-\mathrm{O}(6)$ & $2.04(2)$ \\
\hline $\mathrm{O}(7) \# 2-\mathrm{Fe}(1)-\mathrm{O}(4)$ & $169.9(1)$ & $\mathrm{O}(6) \# 2-\mathrm{Fe}(1)-\mathrm{O}(4)$ & $95.5(3)$ \\
\hline $\mathrm{O}(2)-\mathrm{Fe}(1)-\mathrm{O}(4)$ & $90.3(1)$ & $\mathrm{O}(1 \mathrm{~W})-\mathrm{Fe}(1)-\mathrm{O}(4)$ & $81.7(1)$ \\
\hline $\mathrm{O}(7) \# 2-\mathrm{Fe}(1)-\mathrm{O}(6)$ & $110.2(1)$ & $\mathrm{O}(6) \# 2-\mathrm{Fe}(1)-\mathrm{O}(6)$ & $77.3(1)$ \\
\hline $\mathrm{O}(2)-\mathrm{Fe}(1)-\mathrm{O}(6)$ & $84.5(2)$ & $\mathrm{O}(1 \mathrm{~W})-\mathrm{Fe}(1)-\mathrm{O}(6)$ & $161.3(1)$ \\
\hline $\mathrm{O}(4)-\mathrm{Fe}(1)-\mathrm{O}(6)$ & $79.6(1)$ & & \\
\hline \multicolumn{4}{|l|}{ Complex 3} \\
\hline $\mathrm{Fe}(1)-\mathrm{O}(10)$ & $1.96(4)$ & $\mathrm{Fe}(1)-\mathrm{O}(5)$ & $1.99(4)$ \\
\hline $\mathrm{Fe}(1)-\mathrm{O}(7)$ & $2.01(3)$ & $\mathrm{Fe}(1)-\mathrm{O}(12)$ & $2.01(4)$ \\
\hline $\mathrm{Fe}(1)-\mathrm{O}(14)$ & $2.04(3)$ & $\mathrm{Fe}(1)-\mathrm{O}(16)$ & $2.07(4)$ \\
\hline $\mathrm{O}(10)-\mathrm{Fe}(1)-\mathrm{O}(5)$ & $167.7(2)$ & $\mathrm{O}(10)-\mathrm{Fe}(1)-\mathrm{O}(7)$ & $96.3(3)$ \\
\hline $\mathrm{O}(5)-\mathrm{Fe}(1)-\mathrm{O}(7)$ & $87.4(2)$ & $\mathrm{O}(7)-\mathrm{Fe}(1)-\mathrm{O}(12)$ & $157.5(1)$ \\
\hline $\mathrm{O}(10)-\mathrm{Fe}(1)-\mathrm{O}(12)$ & $94.4(3)$ & $\mathrm{O}(5)-\mathrm{Fe}(1)-\mathrm{O}(12)$ & $87.4(1)$ \\
\hline
\end{tabular}

Symmetry code: $(\# 1)-x+1,-y+1,-z+1 ;(\# 2)-x+1,-y+1,-z$.

\section{4. $\left[\mathrm{Fe}_{4}(\mathrm{cit})_{4}\left(\mathrm{H}_{2} \mathrm{O}\right)_{4}\right]\left(\mathrm{H}_{2} \mathrm{bpp}\right)_{2} \cdot \mathrm{H}_{2} \mathrm{O}$ (3)}

Compound 3 was synthesized under the same condition and ratio except for the bpp $(0.196 \mathrm{~g}, 1 \mathrm{mmol})$ instead of bpa. Yellow block of $\mathbf{3}$ for X-ray diffraction study and other measurements were manually collected under a microscope. Anal. Calc. for $\mathrm{C}_{50} \mathrm{H}_{60} \mathrm{Fe}_{4} \mathrm{~N}_{2} \mathrm{O}_{33}$ (3): C, 40.90; H, 4.12; N, 3.82. Found: C, 40.78; H, 4.20; N, $3.86 \%$ IR ( $\left.\mathrm{KBr} \mathrm{cm}^{-1}\right): 3082(\mathrm{~s}), 2918(\mathrm{w}), 2157(\mathrm{~s}), 1627(\mathrm{v})$, 1500(s), 1374(v), 1248(v), 1084(v), 843(v), 640(v), 457(v).

\subsection{Crystal structure determination}

X-ray diffraction data were collected on a BRUKER SMART APEX CCD diffractometer with Mo $\mathrm{K} \alpha$ radiation $(\lambda=0.71073 \AA)$ at $298(2) \mathrm{K}$. The structures were solved by direct methods and refined by full-matrix leastsquares on $F^{2}$ with SHELXL-97 program package [8]. The non-hydrogen atoms were located with difference Fourier synthesis, and the hydrogen atoms were generated geometrically, except for the $\mathrm{N}-\mathrm{H}$ and water $\mathrm{H}$ atoms which were located from different Fourier maps. The crystallographic data for 1, 2 and 3 are listed in Table 1, selected bond lengths and angles are presented in Table 2 and hydrogen bonding is shown in Table 3 (Supporting information).

\section{Results and discussion}

\subsection{Description of structures}

The hydrothermal reaction of ferric nitrate, sodium citrate, bpa, bpe and bpp, with a molar ratio of $2: 1: 1$, in $\mathrm{H}_{2} \mathrm{O}$ at $150{ }^{\circ} \mathrm{C}$ for 7 days, produced yellow crystals of $\left(\mathrm{H}_{2} \mathrm{bpa}\right)$ $\left[\mathrm{Fe}_{2}(\mathrm{cit})_{2}\left(\mathrm{H}_{2} \mathrm{O}\right)_{2}\right] \quad(\mathbf{1}) ; \quad\left(\mathrm{H}_{2}\right.$ bpe $)\left[\mathrm{Fe}_{2}(\mathrm{cit})_{2}\left(\mathrm{H}_{2} \mathrm{O}\right)_{2}\right] \quad$ (2) and $\left(\mathrm{H}_{2} \mathrm{bpp}\right)_{2}\left[\mathrm{Fe}_{4}(\mathrm{cit})_{4}\left(\mathrm{H}_{2} \mathrm{O}\right)_{4}\right]_{2} \cdot \mathrm{H}_{2} \mathrm{O}(3)$, which were structurally characterized by $\mathrm{X}$-ray single crystal diffraction and confirmed by powder X-ray diffraction (PXRD) analyses (Supporting Information, Figure S1). Some minor 
disagreements in the intensities of peaks in the simulated and measured PXRD patterns are due to preferred orientations of the microcrystals. The anionic of $\mathbf{1}$ is an edge-shared bi-octahedral dimer with centro-symmetric structure, in which the two iron atoms are bridged by two alkoxide oxygen atoms of the fully deprotonated citrate ligands. All of the carboxylate groups coordinate in a mono-dentate fashion to terminal positions, and two water molecules complete the slightly distorted octahedral coordination spheres (as shown in Fig. 1). This structure is very similar to the reported $(\mathrm{Hpy})_{2}\left[\mathrm{Fe}_{2}(\mathrm{cit})_{2}\left(\mathrm{H}_{2} \mathrm{O}\right)_{2}\right] \cdot 2 \mathrm{H}_{2} \mathrm{O}$ complex in the literature $[5 \mathrm{e}]$. The chelating of the deprotonated hydroxyl and carboxylic groups of the citrate ion lead to two six-membered rings and one five-membered ring, perhaps stabilizing the overall dimeric moiety. The $\mathrm{Fe}-\mathrm{O}$ bond lengths range from $1.9682(2) \AA$ to $2.0294(19) \AA$. Further perusal of the literature reveals that this complex is isostructural with the $\mathrm{V}^{2+}, \mathrm{Fe}^{3+}, \mathrm{Ni}^{2+}, \mathrm{Zn}^{2+}$ and $\mathrm{Cu}^{2+}$ analogues $[9,5 \mathrm{e}]$. The $\mathrm{M}-\mathrm{O}$ distances observed in the $\mathrm{Zn}, \mathrm{V}$, $\mathrm{Fe}$ and $\mathrm{Ni}$ complexes compare favorably with those observed in 1 and are in the range of 2.052(2)-2.164(2) $\AA$ $\left(\mathrm{Zn}^{2+}\right), \quad 1.992(3)-2.041(3) \AA\left(\mathrm{V}^{2+}\right), \quad 1.987(3)-2.0383(3) \AA$ $\left(\mathrm{Fe}^{3+}\right)$ and 2.021(3)-2.072(3) $\AA\left(\mathrm{Ni}^{2+}\right)$, while a wider range due to Jahn-Teller distortion is observed in the copper

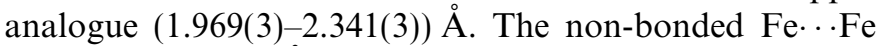
distance is 3.14(6) $\AA$, which separation is subject to major control by the mutual steric requirements of the metal coordination spheres, and the $\mathrm{O}-\mathrm{Fe}-\mathrm{O}$ angle in the four-membered $\mathrm{Fe}_{2} \mathrm{O}_{2}$ is $77.83(8)^{\circ}$, which shows that the $\sigma$-hybridization of bridging oxygen is near $\mathrm{sp}^{3}[10]$. The principle presented by Parai-Koshits says that when a structure with a center of symmetry is one of several differences in energy, it is usually found that the centrosymmetric structure is favored by the crystal packing [11]. The complex anion has a crystallographically imposed center of symmetry, and the molecular symmetry is $C_{i}$.

The $\mathrm{O}-\mathrm{H} \cdots \mathrm{O}$ hydrogen-bonding interactions $(\mathrm{O}(15)$ $\mathrm{H} 15 \mathrm{C} \cdots \mathrm{O} 2)$ and $(\mathrm{O}(16)-\mathrm{H} 16 \mathrm{C} \cdots \mathrm{O} 1)$ between the coordinated water molecules of $\left[\mathrm{Fe}_{2}(\mathrm{cit})_{2}\left(\mathrm{H}_{2} \mathrm{O}\right)_{2}\right]^{2-}$ anion and $-\mathrm{COO}^{-}$group of the other adjacent anion lead to the formation of the one-dimensional chain motif in complex 1 (see Table 3). And these binuclear units are held together by means of $\mathrm{H}$ bonds involving the coordinated water, oxygen atoms of un-coordinated carboxylates and $\mathrm{N}$ atoms of deprotonated bpa molecules, which further assemble into a 2D supramolecular sheet. It is convenient to consider the formation of the two-dimensional structure in terms of the one-dimensional substructure generated by the anions alone and the linking of the anion chain by the cation (as shown in Fig. 2). It noted that there is a short and nearly linear $\mathrm{N}-\mathrm{H} \cdots \mathrm{O}$ hydrogen bond, whose strength is a consequence of both donor and acceptor being charged, thus $\mathrm{N}^{+}-\mathrm{H} \cdots \mathrm{O}^{-}[12]$.

In the reference anionic complex $\left[\mathrm{Fe}_{2}(\mathrm{cit})_{2}\left(\mathrm{H}_{2} \mathrm{O}\right)_{2}\right]^{2-}$, oxygen atoms of coordinated water acts as hydrogen-bond donor to $\mathrm{O} 3$ and $\mathrm{O} 5$. Propagation of these interactions produce a chain of fused rings running parallel to the [100] direction in which there are $R_{2}^{2}(8)$ rings centered at alternating with $R_{2}^{2}(8)$ rings [the number of donors (d) and acceptors (a) used in each motif are assigned as subscripts and superscripts, respectively, and the size or degree of the motif (corresponding to the number of atom in the repeat unit) is indicated in the parentheses.] [13]. Chains of this type are linked by the cations N1 acting as a hydrogen-bond donor to $\mathrm{O} 7$ and hence a $C_{2}^{2}(18)$ chain is generated by translation, running to the [010] direction [13]. The combination of the [100] chains of anions and the $[010]$ chains of the alternating cations and anions gener-

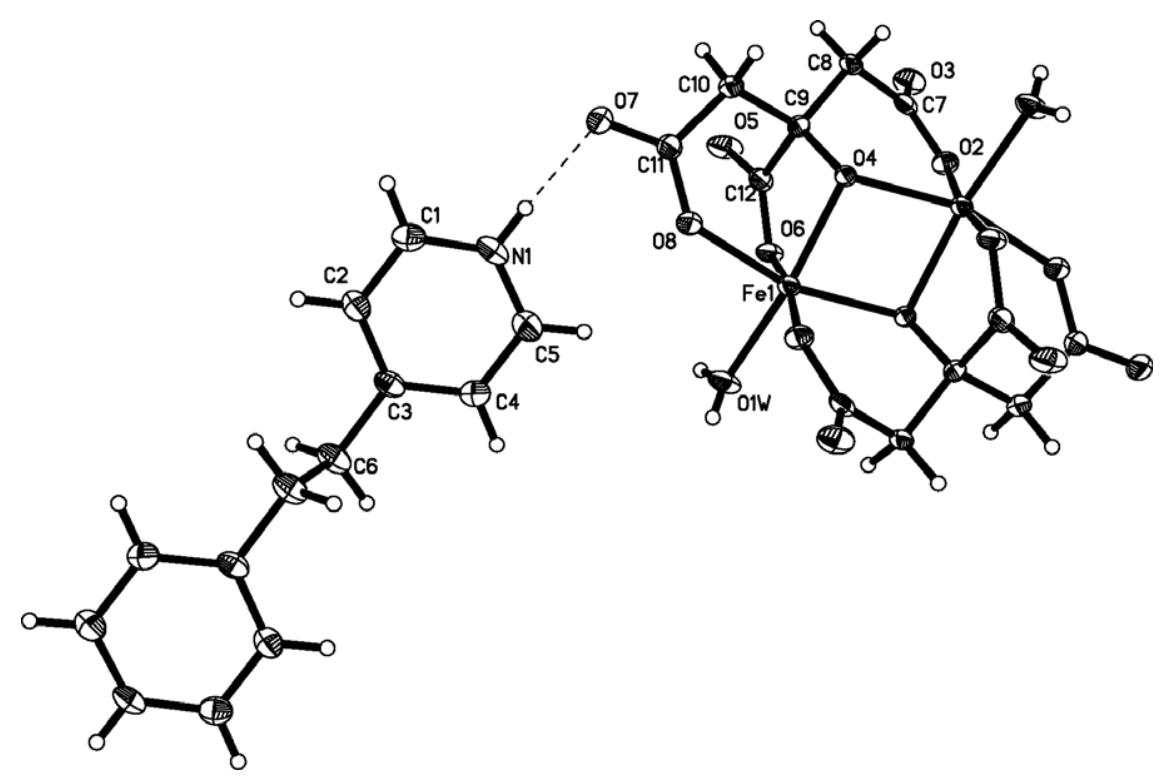

Fig. 1. Structure of the $\left[\mathrm{Fe}_{2}(\mathrm{cit})_{2}\left(\mathrm{H}_{2} \mathrm{O}\right)_{2}\right]\left(\mathrm{H}_{2}\right.$ bpa) complex. Displacement ellipsoids are drawn at the $30 \%$ probability level. (The $\mathrm{H}_{2}$ bpp cation is omitted for clarity, the symmetric code: (i) $-x+2,-y+2,-z+2$, (ii) $-x+1,-y+1,-z+1$.) 


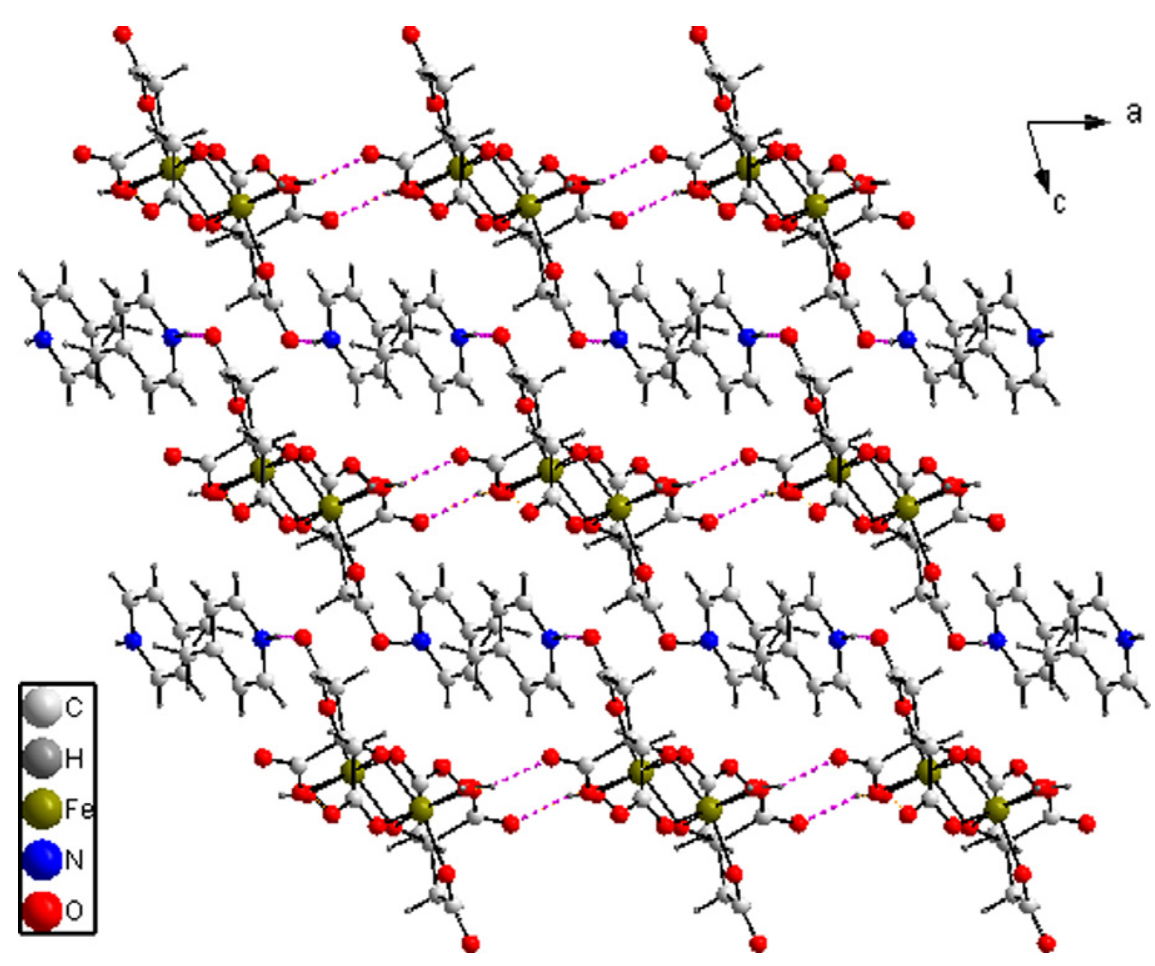

Fig. 2. Part of the crystal structure of (1) showing the formation of the sheet built from $R_{6}^{6}(50)$ and $R_{6}^{4}(48)$ rings.

ated sheet in which the anti-parallel cations are separated by large centero-symmetric rings, alternately of $R_{6}^{6}(50)$ and $R_{6}^{4}(48)$ type [13] (as shown in Fig. 2). For these hydrogen bonds, the shortest $\mathrm{O}$. . O separation is 2.594(4) $\AA$; the bond angles are in the range of $122.64-171(11)^{\circ}$. All the relevant hydrogen-bonding geometries are in the normal range for such strong interactions. In addition, the sheets are linked into a single three-dimensional framework by single weak $\mathrm{C}-\mathrm{H}$... O hydrogen-bonding. Atom $\mathrm{C} 5$ in the cation, part of the ethane spacer unit between the heteroaromatic rings, act as hydrogen-bond donor to $\mathrm{O}$, similarly, a component of the reference sheet of atom $\mathrm{C} 8$ and $\mathrm{C} 1$, acts as a hydrogen-bond donor to $\mathrm{O} 3 \mathrm{~A}$ and $\mathrm{O} 2$, respectively. In this manner, each sheet is linked to its two immediate neighbors, thus generating a continuous three-dimensional framework (Fig. S2). What is more, notable feature of exoteric bpa molecules parallel with each other when involving hydrogen bonds interactions.

The unit cell of $\mathbf{2}$ is made up of one protonated [bpe $]^{2+}$ cation and one discrete binuclear iron (III) citrate anionic $\left[\mathrm{Fe}_{2}(\mathrm{cit})_{2}\left(\mathrm{H}_{2} \mathrm{O}\right)_{2}\right]^{2-}$. The center Fe ion has the similar coordinated mode to 1 , and the non-bonded $\mathrm{Fe} \cdots \mathrm{Fe}$ distance is $3.143 \AA$, which is very close to above 1 . As far as we are aware, four iron (III) citrate complexes have been prepared and crystallographically characterized [14,5f], i.e., $(\mathrm{Hpy})_{2}$ $\left[\mathrm{Fe}_{2}(\mathrm{cit})_{2}\left(\mathrm{H}_{2} \mathrm{O}\right)_{2}\right] \cdot 2 \mathrm{H}_{2} \mathrm{O}$ (py = pyridine), $(\mathrm{Hneo})_{2}\left[\mathrm{Fe}_{2}(\mathrm{Hcit})_{3}\right] \cdot$ $n \mathrm{H}_{2} \mathrm{O}$ (neo = neocuproine), $(\mathrm{Hneo})_{7}\left[\mathrm{Fe}_{9} \mathrm{O}(\mathrm{cit})_{8}\left(\mathrm{H}_{2} \mathrm{O}\right)_{3}\right] \cdot$ neo . $61 \mathrm{H}_{2} \mathrm{O}$ and $(\mathrm{Hql})_{2}\left[\mathrm{Fe}_{2}(\mathrm{cit})_{2}\left(\mathrm{H}_{2} \mathrm{O}\right)_{2}\right] \cdot 4 \mathrm{H}_{2} \mathrm{O}(\mathrm{ql}=$ quinoline $)$. The condition for preparing $(\mathrm{Hpy})_{2}\left[\mathrm{Fe}_{2}(\mathrm{cit})_{2}\left(\mathrm{H}_{2} \mathrm{O}\right)_{2}\right]$. $2 \mathrm{H}_{2} \mathrm{O}$ and $(\mathrm{Hneo})_{7}\left[\mathrm{Fe}_{9} \mathrm{O}(\mathrm{cit})_{8}\left(\mathrm{H}_{2} \mathrm{O}\right)_{3}\right] \cdot$ neo $\cdot 61 \mathrm{H}_{2} \mathrm{O}$ are similar, which are obtained from the an aqueous solution.
Zhang et al. speculate that poly-iron complexes other than $\left\{\mathrm{Fe}_{2}\right\}$ and $\left\{\mathrm{Fe}_{9}\right\}$ may also exist in equilibrium in these solutions and can be crystallized by using the appropriate counterions [5f]. Although the polynuclear iron complexes were not obtained, of the interesting, all of the ligands are also deprotonated, which serves as the counterion of the anionic complex $\left[\mathrm{Fe}_{2}(\mathrm{cit})_{2}\left(\mathrm{H}_{2} \mathrm{O}\right)_{2}\right]^{2-}$, it notes that the $\mathrm{H}_{2}$ bpe cations are vertical between adjacent molecules when hydrogen-bonded to oxygen atoms of un-coordinated carboxyl group, which are very different from the flexible mode of $\mathrm{H}_{2}$ bpa cations. As shown in Fig. 3.

In Fig. 3, at the distal ends of these bipyridine units, $\mathrm{N} 1$ acts as a donor to O3, thus generating a $C_{3}^{3}(22)$ chain running parallel to the [010] [13]. Each type of chain involves just one type of bipyridine, but both types of citrate, the combination of the [100] anion chain and the two $C_{3}^{3}(22)$ chains of cations and anions generates two sheets, alternating $R_{6}^{6}(50)$ and $R_{6}^{4}(48)$ type in ac plane [13].

Both of the counterions $\mathrm{H}_{2} \mathrm{bpa}^{2+}$ and $\mathrm{H}_{2} \mathrm{bpe}^{2+}$ are uncoordinated in structures $\mathbf{1}$ and $\mathbf{2}$, respectively,. There are no differences in negativity of $\mathrm{H}$-bond donor centre arising from their different sizes. Thus the same number and modes of H-bonds $\left(R_{6}^{6}(50)\right.$ and $R_{6}^{4}(48)$ type) associate with them. However, the significant different array can attribute to the conformations of the ligands when they associate with the anionic complex (the feature of exoteric bpa molecules parallel with each other when involved hydrogen-bonding interactions in $\mathbf{1}$, in contrast the mode of bpe shows vertical motif). In the complex (Hpy) ${ }_{2}-$ $\left[\mathrm{Fe}_{2}(\mathrm{cit})_{2}\left(\mathrm{H}_{2} \mathrm{O}\right)_{2}\right] \cdot 2 \mathrm{H}_{2} \mathrm{O}$ (py = pyridine) [13a], hydrogen 


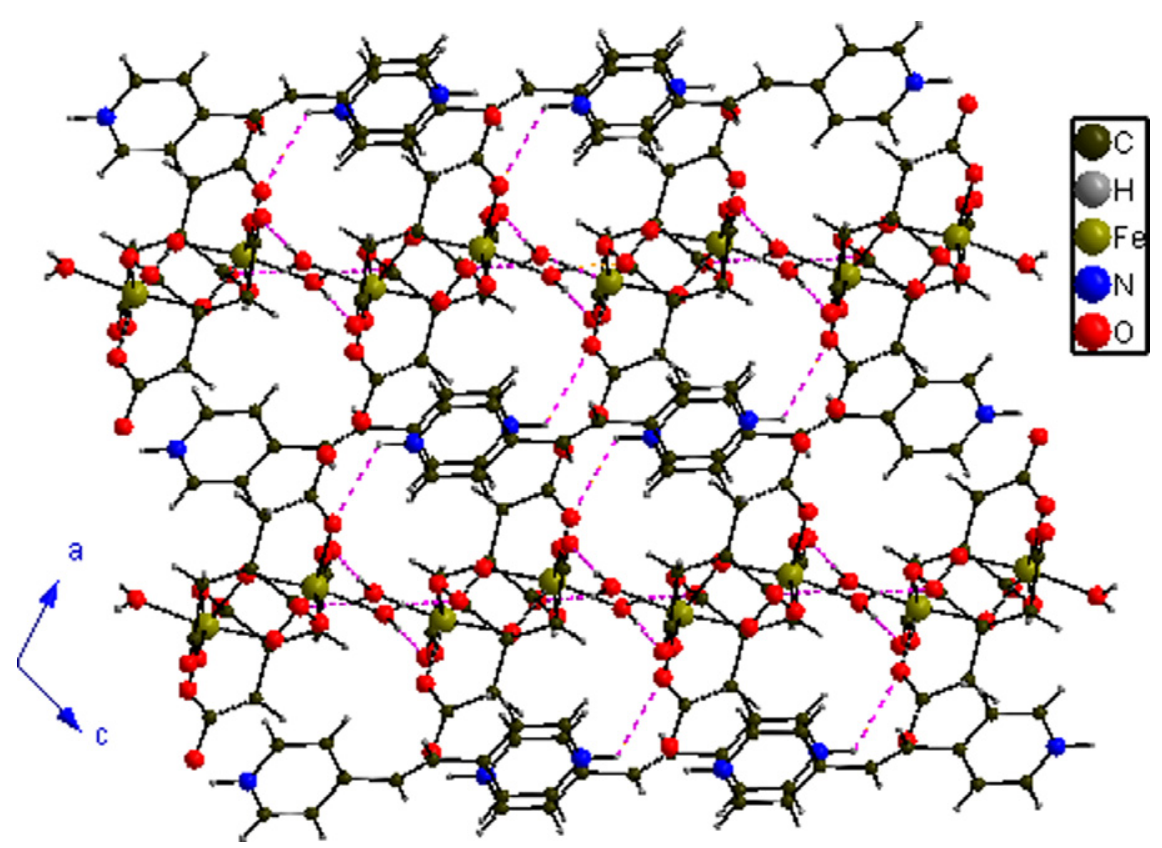

Fig. 3. Part of the crystal structure of (2) showing the formation of the sheet built from $R_{6}^{6}(50)$ and $R_{6}^{4}(48)$ rings.

bonding patterns between $\left[\mathrm{Fe}_{2}\left(\mathrm{cit}_{2}\left(\mathrm{H}_{2} \mathrm{O}\right)_{2}\right]^{2-}\right.$ and lattice water moieties, and $\left[\mathrm{Fe}_{2}(\mathrm{cit})_{2}\left(\mathrm{H}_{2} \mathrm{O}\right)_{2}\right]^{2-}$ and $\mathrm{Hpy}^{+}$are shown in Fig. S3. An 18-membered ring $\left[R_{4}^{4}(18)\right]$ formed by anions and coordinated and lattice water molecules via the H-bonding interactions and resulted an infinite chain, and a 4-membered ring formed by the oxygen atoms of the uncoordinated carboxylate group and the lattice water. The two sets of rings share the H-bonding link $[\mathrm{O} 2-\mathrm{H}(13) \cdots \mathrm{O}(9)]$, thereby forming $2 \mathrm{D}$ network of graph sets. The protonated Hpy is engaged in one $\mathrm{H}$-bonding interaction with oxygen atoms (O5) of the uncoordinated carboxylate group, and fling into the above 18 -membered ring. The different supramolecular structures of $\mathbf{1 , 2}$ and the $(\mathrm{Hpy})_{2}\left[\mathrm{Fe}_{2}-(\mathrm{cit})_{2}\left(\mathrm{H}_{2} \mathrm{O}\right)_{2}\right] \cdot 2 \mathrm{H}_{2} \mathrm{O}$ complex show different motifs, the lattice water molecules in the $(\mathrm{Hpy})_{2}\left[\mathrm{Fe}_{2}-\right.$ (cit) $\left.{ }_{2}\left(\mathrm{H}_{2} \mathrm{O}\right)_{2}\right] \cdot 2 \mathrm{H}_{2} \mathrm{O}$ complex affect the number and modes of $\mathbf{H}$-bonds in comparison to the $\mathbf{1}$ and $\mathbf{2}$.
The structure of supramolecular complex 3 consists of two asymmetric binuclear anionic units, two $\mathrm{H}_{2}$ bpp cations and one lattice water, as shown in Fig. 4. The coordinated environment of $\mathrm{Fe}$ atoms is very close to $\mathbf{1}$ and $\mathbf{2}$. The bpp molecule adopts $\mathrm{T} \cdot \mathrm{T}$ conformation ( $\mathrm{N}$-to- $\mathrm{N}$ distance is $9.528 \AA$ in this work; the different conformations are attributed to the different $\mathrm{N}$-to- $\mathrm{N}$ distances, such as, the distance range of TT conformation is 9.1-10.1 $\AA$ ) [15]. When refer to hard hydrogen bonds, which is similar to 1 . Propagation of these interactions produce a chain of fused rings running parallel to the [1 00 ] direction in which there are $R_{2}^{2}(10)$ rings centered at alternating with $R_{2}^{2}(10)$ rings [13]. Chains of this type are linked by the cations $\mathrm{N} 1$ acting as a hydrogen-bond donor to $\mathrm{O} 13$ and hence a $C_{2}^{2}(20)$ chain is generated by translation, running to the $\left[\begin{array}{ll}0 & 0\end{array}\right]$ direction. Thus, the combination of the [ 100$]$ chains of anions and the [001] chains of the alternating cations and anions generated sheet in which

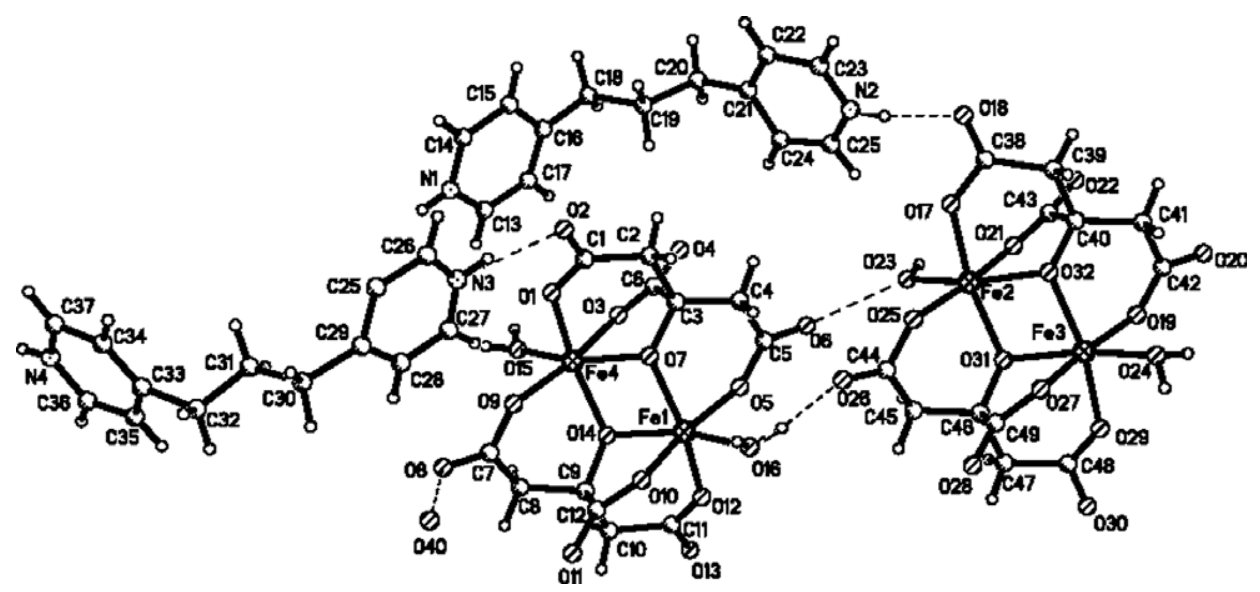

Fig. 4. Structure of $\left[\mathrm{Fe}_{4}(\mathrm{cit})_{4}\left(\mathrm{H}_{2} \mathrm{O}\right)_{4}\right]\left(\mathrm{H}_{2} \mathrm{bpp}\right)_{2} \cdot \mathrm{H}_{2} \mathrm{O}$ complex. Displacement ellipsoids are drawn at the $30 \%$ probability level. 


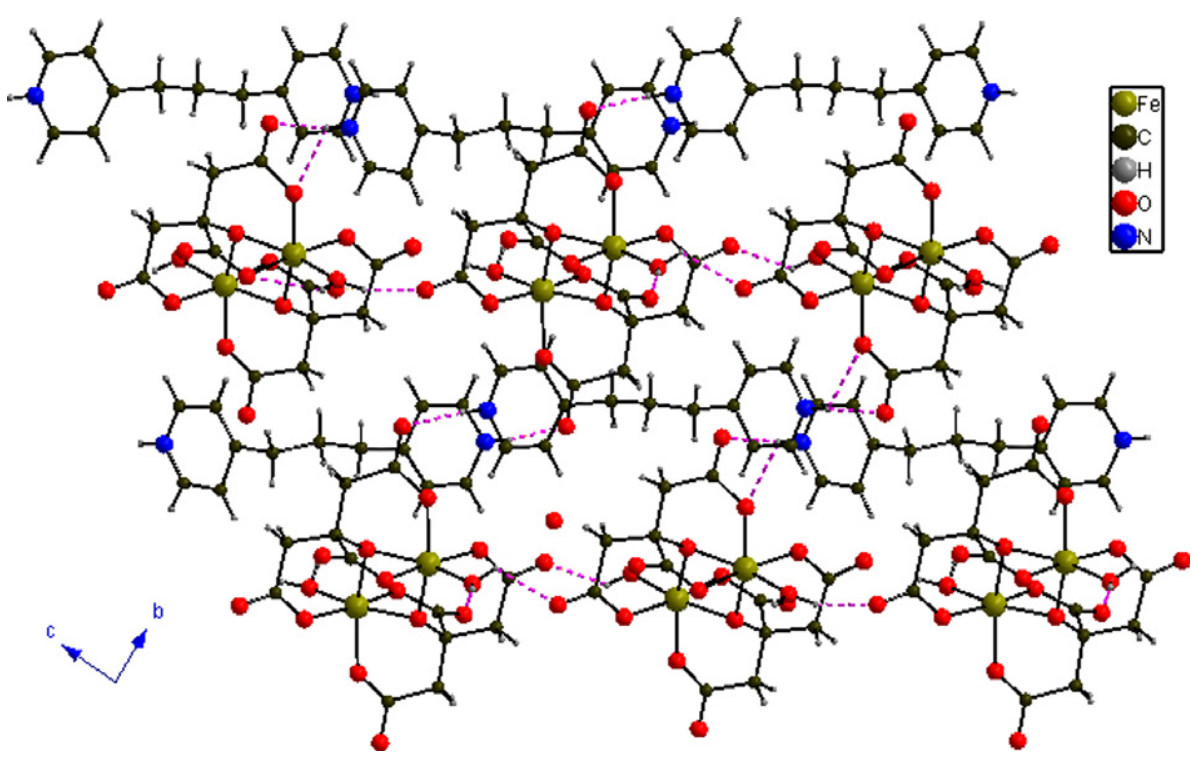

Fig. 5. Part of the crystal structure of (3) showing the formation of the sheet built from $R_{6}^{6}(51)$ and $R_{6}^{4}(49)$ rings.

the anti-parallel cations are separated by large centro-symmetrical rings, alternately of $R_{6}^{6}(51)$ and $R_{6}^{4}(49)$ type [13]. Within the bipyridyl unit, the dihedral angle between the ring plane is $10.2(2)^{\circ}$. Each bipyridyl ring forms weak $\pi \cdots \pi$ stacking interactions $(3.384 \AA$ ) with bipyridyl units in the two adjacent sheet (as shown in Fig. 5).

\subsection{Electronic spectroscopy}

The UV/Vis spectroscopy of complexes $\mathbf{1}-\mathbf{3}$ were conducted in an aqueous solution at $\mathrm{pH} \sim 7$, However, the spin- and parity-forbidden transitions of the high-spin in 1-3 are very weak [16], being hardly observable. All of them in water at $\mathrm{pH} \sim 7$ are featureless in the visible region with sharply ascending absorption into the UV region leading to a band at approximate $250 \mathrm{~nm}$, most likely reflecting LMCT absorption [17] (as shown in Fig. S4 (Supporting information)).

\subsection{FT-IR spectroscope}

The FT-IR spectra of $\mathbf{1 - 3}$ (in $\mathrm{KBr}$ ) exhibit strong characteristic absorptions for the carboxyl of citrate carboxylate ligands in the asymmetric and symmetric vibration regions. Specifically, asymmetric stretching vibration $v_{\text {as }}\left(\mathrm{COO}^{-}\right)$appear between 1629 and $1501 \mathrm{~cm}^{-1}$ for $\mathbf{1}$, between 1628 and $1501 \mathrm{~cm}^{-1}$ for 2 and between 1627 and $1503 \mathrm{~cm}^{-1}$ for 3 and the symmetric stretching vibration $v_{\mathrm{s}}\left(\mathrm{COO}^{-}\right)$are observed $1358 \mathrm{~cm}^{-1}$ for $\mathbf{1}$, between 1410 and $1369 \mathrm{~cm}^{-1}$ for 2 and between 1403 and $1374 \mathrm{~cm}^{-1}$ for 3. For among the three complexes, the difference between the asymmetric and symmetric stretches, $\Delta v_{\text {as }}\left(\mathrm{COO}^{-}\right)-v_{\mathrm{as}}\left(\mathrm{COO}^{-}\right)$, are on the order of $200 \mathrm{~cm}^{-1}$ indicating that carboxyl groups are either free or coordinated to the metal in a mono-dentate fashion [18], consistent with the observed X-ray crystal structures of 1-3.

\subsection{Magnetic susceptibility}

Variable-temperature magnetic susceptibilities for 1-3 are collected in the $2-300 \mathrm{~K}$ temperature range and are shown as $\chi_{\mathrm{M}} T$ and $\chi_{\mathrm{M}}$ versus $T$ plots in Fig. 6. The $\chi_{\mathrm{M}} T$ values are $7.3 \mathrm{~cm}^{3} \mathrm{~K} \mathrm{~mol}^{-1}, \quad 7.2 \mathrm{~cm}^{3} \mathrm{~K} \mathrm{~mol}^{-1}$ and $6.9 \mathrm{~cm}^{3} \mathrm{~K} \mathrm{~mol}^{-1}$ for $\mathbf{1}, \mathbf{2}$ and $\mathbf{3}$ at room temperature, respectively, which are somewhat smaller than the expected value $8.37 \mathrm{~cm}^{3} \mathrm{~K} \mathrm{~mol}^{-1}$ calculated for two isolated $\mathrm{Fe}^{3+}$ ions with high-spin state $(S=5 / 2)$, but comparable to those values observed in some complexes with strong anti-ferromagnetic coupling interaction between the two iron centers [19]. Upon cooling, the $\chi_{\mathrm{M}}$ exhibits a rounded maximum around $2 \mathrm{~K}$, while the $\chi_{\mathrm{M}} T$ value continuously decreases to $0.2 \mathrm{~cm}^{3} \mathrm{~K} \mathrm{~mol}^{-1}$ at $2 \mathrm{~K}$ for the three complexes, which indicate of anti-ferromagnetic behavior. Assuming isotropic exchange, the experimental magnetic datum were simulated for the dimeric $\mathrm{Fe}$ (III) system based on the spin Hamiltonian is expressed as $\widehat{H}=-2 \mathrm{~J} \widehat{S}_{1} \cdot \widehat{S}_{2}$ with the following equation [20]:

$\chi_{\mathrm{M}}=(1-P) \chi_{\mathrm{M}}^{\prime}+2 P \chi_{\mathrm{c}}+$ TIP

$\chi_{\mathrm{M}}^{\prime}=\frac{N_{\mathrm{A}} g^{2} \mu_{\mathrm{B}}^{2}\left(2 e^{2 y}+10 e^{6 y}+28 e^{12 y}+60 e^{20 y}+110 e^{30 y}\right)}{\mathrm{KT}\left(1+3 e^{2 y}+5 e^{6 y}+7 e^{12 y}+9 e^{20 y}+11 e^{30 y}\right)}$

$y=\mathrm{J} / \mathrm{KT}$

$\chi_{\mathrm{c}}=N_{\mathrm{A}} g^{2} \mu_{\mathrm{B}}^{2} S(S+1) / 3 \mathrm{KT}$

where $P$ is the percentage of paramagnetic impurity, TIP is temperature-independent paramagnetism, $N_{\mathrm{A}}$ is Avogadro constant $\left(6.022 \times 10^{23} \mathrm{~mol}^{-1}\right), g$ is Landé factor, $\mu_{\mathrm{B}}$ is Bohr magneton $\left(9.274 \times 10^{-21} \mathrm{~J} \mathrm{~T}^{-1}\right), k$ is Boltzmann constant temperature, $J$ is coupling constant, and $S$ is spin multiplicity $\left(5 / 2\right.$ for high-spin $\left.\mathrm{Fe}^{3+}\right)$. The best fit parameters are $J=-7.4 \mathrm{~cm}^{-1},-6.2 \mathrm{~cm}^{-1}$ and $-6.7 \mathrm{~cm}^{-1} ; g=1.95,1.96$ and $1.99 ; P=1.35(2) \%, 1.56(2) \%$ and $1.48(2) \%$ and the 

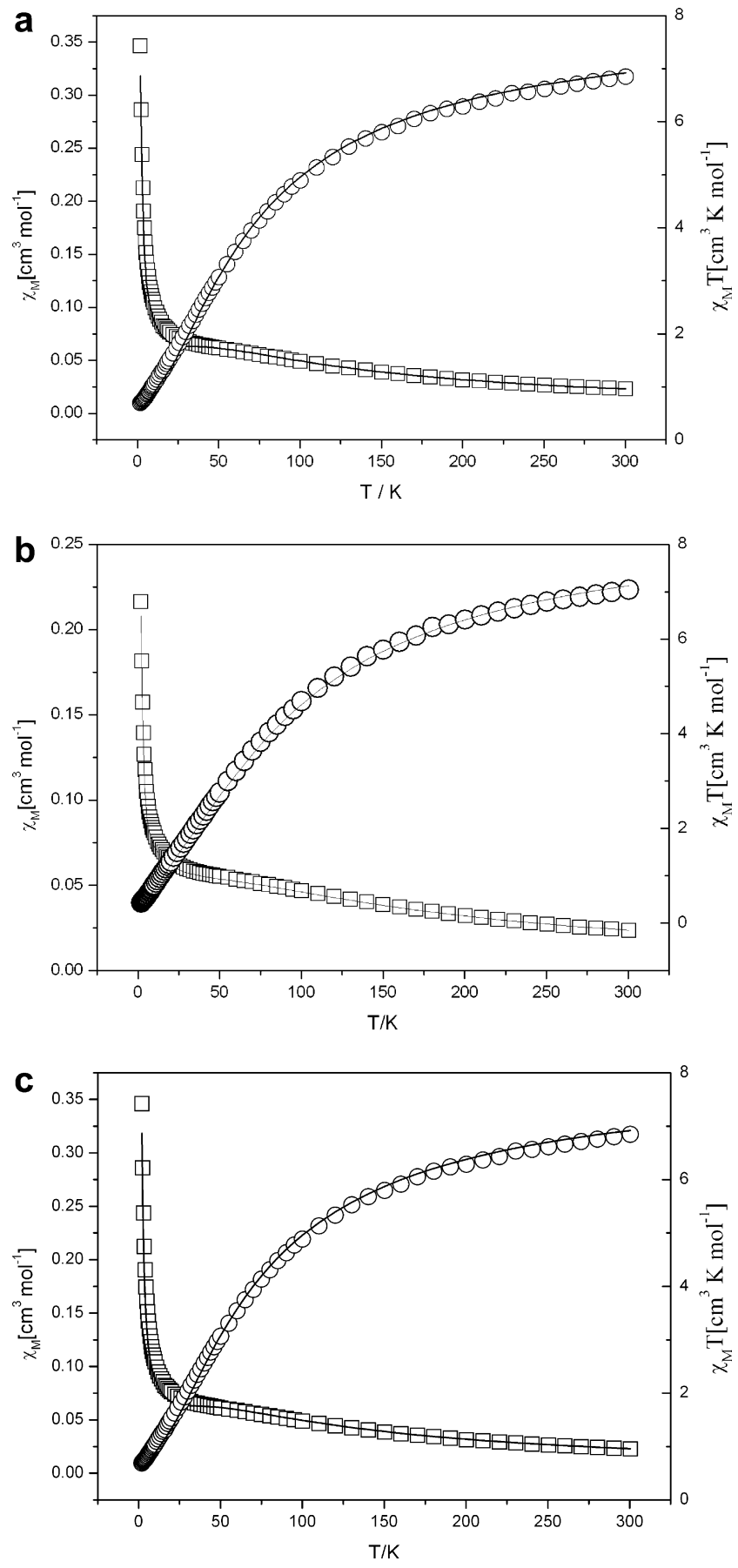

Fig. 6. (a) Plots of the experimental and theoretic temperature dependence of $\chi_{\mathrm{M}}$ and $\chi_{\mathrm{M}} T$ for 1 (solid line represent the theoretical fits). (b) Plots of the experimental and theoretic temperature dependence of $\chi_{\mathrm{M}}$ and $\chi_{\mathrm{M}} T$ for 2 (solid line represent the theoretical fits). (c) Plots of the experimental and theoretic temperature dependence of $\chi_{\mathrm{M}}$ and $\chi_{\mathrm{M}} T$ for 1 (solid line represent the theoretical fits).

final $R=8.9 \times 10^{-4}, 7.6 \times 10^{-4}$ and $3.4 \times 10^{-4}$ for $\mathbf{1}-\mathbf{3}$, respectively. Where $R$ is defined as $\Sigma\left(\chi_{\mathrm{M}}^{\text {obs }}-\chi_{\mathrm{M}}^{\text {calc }}\right)^{2} /\left(\chi_{\mathrm{M}}^{\text {obs }}\right)^{2}$.

The above range of negative $J$ value is observed for other dialkoxo- or dihydroxo-bridged diiron(III) complexes [21]. $J$ values of some diiron complexes using the formalism are listed in Table 3. We observe for the exchange couplings in $\mathbf{1 - 2}$ is that they display very approximate values due to their close structural resemblance, this similar value is observed in the $(\mathrm{Hql})_{2}\left[\mathrm{Fe}_{2}(\mathrm{cit})_{2}\left(\mathrm{H}_{2} \mathrm{O}\right)_{2}\right]$. $4 \mathrm{H}_{2} \mathrm{O}$ complex [5f], however, a compared low value $\left(J=-4.5 \mathrm{~cm}^{-1}\right)$ is observed in the $(\mathrm{Hpy})_{2}\left[\mathrm{Fe}_{2}(\mathrm{cit})_{2}\left(\mathrm{H}_{2} \mathrm{O}\right)_{2}\right]$. $2 \mathrm{H}_{2} \mathrm{O}[5 \mathrm{e}]$. It can easily be seen in the literature that there is an important spread of derived coupling constants for complexes with similar structures, attributable to experimental errors and to different measurement and analysis procedures employed in various cases [22]. It may be more difficult to come to straightforward correlations, and more elaborate theoretical studies will be required. The extent of antiferromagnetism exhibited by the title complexes ( $\mathbf{1}$ and 2 complexes) is comparable to that reported for other carboxylate-bridged diiron(III) complexes, the magnetic properties of carboxylate-bridged diiron(III) complexes depend significantly on the nature of the bridging ligands [23]. For example, the values for $J$ vary between -13 and $-26 \mathrm{~cm}^{-1}$ for hydroxo and alkoxo carboxylate-bridged complexes [24]. The complex 3 contains two same dimeric $\left[\mathrm{Fe}_{2}(\mathrm{cit})_{2}\left(\mathrm{H}_{2} \mathrm{O}\right)_{2}\right]^{2-}$ core, the host is very close to the complex $\mathbf{1}$ and $\mathbf{2}$, the coupling constant is also somewhat bigger than the $(\mathrm{Hpy})_{2}\left[\mathrm{Fe}_{2}(\mathrm{cit})_{2}\left(\mathrm{H}_{2} \mathrm{O}\right)_{2}\right] \cdot 2 \mathrm{H}_{2} \mathrm{O}$ complex. Focusing on oxo-bridged diferric complexes, similarly, only magneto-structural correlations have been proposed. Gorun and Lippard proposed an exponential dependence of $J$ to the mean super-exchange distance, based on experimental observations on 36 diferric complexes with at least a different bridging ligand [25]. However, no such experimental evidence has been provided to date in oxo-bridged diferric complexes. From Table 3, the data are strongly indicative that variations in one electron orbital overlaps and splittings with the bridging angle do not play a dominant role in determining the degree of antiferromagnetic exchange in these compounds [26].

We had tried to relate this difference in magnetic behavior to the structural differences between the $\mathrm{Fe}_{2} \mathrm{O}_{2}$ moieties and peripheral molecules. However, the complexes 1-3 were found to have hardly evident differences in the pathway of magnetic coupling interaction of the three complexes (Fig. 6). As far as are the structural parameters of three complexes concerned, these structural parameters do not support the stronger interactions $(\mathrm{Fe} \cdots \mathrm{Fe}=3.14 \AA$, $\left.\mathrm{Fe}-\mathrm{O}=1.9682(2)-2.0294(19) \AA, \quad \mathrm{Fe}-\mathrm{O}-\mathrm{Fe}=102.17(4)^{\circ}\right)$ for the three compounds. In fact, it has been stated that the interaction magnitude in oxo-, hydroxo- or dihydroxo-bridged diiron(III) complexes is quite insensitive to the bridging angles and the Fe...Fe distance [27]. Therefore, taking into account that the coordination geometries in the three anionic complexes are very similar, the three complexes have the similar $J$ value. To our knowledge, the coupling between two iron centers in a diiron complex will be anti-ferromagnetic (ferromagnetic) if two octahedral environment are corner-shared or edge-shared (faceshared), and the coupling seems to be enhanced if there is a symmetric center in this dimeric complex. However, this phenomenon has not been found in our complexes. Zhang and co-workers have stated that the face-shared topologi- 
Table 3

Structural and magnetic properties of iron(III) complexes

\begin{tabular}{|c|c|c|c|c|}
\hline Complexes & $J\left(\mathrm{~cm}^{-1}\right)$ & $\mathrm{Fe} \cdot \operatorname{Fe}(\AA)$ & $\mathrm{Fe}-\mathrm{O}-\mathrm{Fe}\left({ }^{\circ}\right)$ & Ref. \\
\hline$(\mathrm{Hpy})_{2}\left[\mathrm{Fe}_{2}(\mathrm{cit})_{2}\left(\mathrm{H}_{2} \mathrm{O}\right)_{2}\right] \cdot 2 \mathrm{H}_{2} \mathrm{O}$ & 4.5 & 3.12 & 101.3 & {$[5 \mathrm{e}]$} \\
\hline$(\mathrm{Hql})_{2}\left[\mathrm{Fe}_{2}(\mathrm{cit})_{2}\left(\mathrm{H}_{2} \mathrm{O}\right)_{2}\right] \cdot 4 \mathrm{H}_{2} \mathrm{O}$ & 6.35 & 3.119 & 101.6 & {$[5 \mathrm{f}]$} \\
\hline$\left[\mathrm{Chelc}\left(\mathrm{H}_{2} \mathrm{O}\right) \mathrm{Fe}(\mathrm{OH})\right]_{2} \cdot 4 \mathrm{H}_{2} \mathrm{O}$ & 7.3 & 3.08 & 103.2 & {$[26 \mathrm{a}]$} \\
\hline$\left[\mathrm{Fe}_{2} \mathrm{O}\left(\mathrm{CO}_{3}\right)_{2}(\mathrm{TACN})_{2}\right]$ & 91.0 & 3.048 & 113.8 & {$[26 \mathrm{~b}]$} \\
\hline$\left[\mathrm{Fe}_{2}\left(\mathrm{CO}_{3}\right)_{2}(\mathrm{medpa})_{2}\right]\left(\mathrm{ClO}_{4}\right)_{2} \cdot 2 \mathrm{H}_{2} \mathrm{O}$ & 110 & 3.06 & 118.2 & {$[26 c]$} \\
\hline$\left[\mathrm{Fe}_{2} \mathrm{~L}\left(\mathrm{OCH}_{3}\right)_{2} \mathrm{Cl}_{2}\right]$ & 15.4 & 3.137 & 102.6 & {$[26 \mathrm{~d}]$} \\
\hline$\left[\mathrm{Fe}_{2} \mathrm{~L}\left(\mathrm{OC}_{2} \mathrm{H}_{5}\right)_{2} \mathrm{Cl}_{2}\right]$ & 16.3 & 3.144 & 104.3 & {$[26 \mathrm{e}]$} \\
\hline$\left[\mathrm{Fe}_{2} \mathrm{~L}_{2}^{\prime}\left(\mathrm{H}_{2} \mathrm{O}\right) 4\right]\left(\mathrm{NO}_{3}\right)\left(\mathrm{H}_{2} \mathrm{O}\right)$ & 0.09 & 3.21 & 115.2 & {$[23]$} \\
\hline$\left[\mathrm{Fe}_{2} \mathrm{~L}_{2}^{\prime}\left(\mathrm{H}_{2} \mathrm{O}\right) 4\right]\left(\mathrm{NO}_{3}\right)\left(\mathrm{H}_{2} \mathrm{O}\right)_{3}$ & 0.21 & 3.08 & 112.3 & {$[23]$} \\
\hline$\left[\mathrm{Fe}_{2} \mathrm{~L}\left(\mathrm{O}_{2} \mathrm{CCH}_{3}\right)_{2}\right] \cdot\left(\mathrm{ClO}_{4}\right)_{2}$ & 1.5 & 3.07 & 118.15 & {$[26 \mathrm{f}]$} \\
\hline$\left[\mathrm{Fe}_{2} \mathrm{~L}^{\prime \prime}(\mathrm{OH}) \mathrm{Cl}_{2}\right] \cdot\left(\mathrm{C}_{4} \mathrm{H}_{8} \mathrm{O}\right)$ & 7.4 & 3.16 & 100.1 & {$[26 \mathrm{~g}]$} \\
\hline$\left[\mathrm{Fe}_{2}(\mathrm{cit})_{2}\left(\mathrm{H}_{2} \mathrm{O}\right)_{2}\right]\left(\mathrm{H}_{2} \mathrm{bpa}\right)$ & 7.3 & 3.139 & 77.83 & this work \\
\hline$\left[\mathrm{Fe}_{2}(\mathrm{cit})_{2}\left(\mathrm{H}_{2} \mathrm{O}\right)_{2}\right]\left(\mathrm{H}_{2} \mathrm{bpe}\right)$ & 7.2 & 3.143 & 77.32 & this work \\
\hline$\left[\mathrm{Fe}_{4}(\mathrm{cit})_{4}\left(\mathrm{H}_{2} \mathrm{O}\right)_{4}\right]\left(\mathrm{H}_{2} \mathrm{bpp}\right)_{2}$ & 6.9 & 3.112 & 77.23 & this work \\
\hline
\end{tabular}

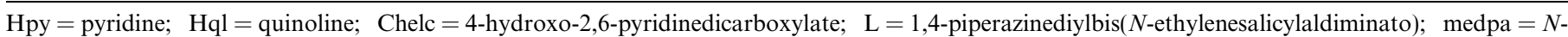
methyl-bis(2-pyridylmethyl) amine; $\mathrm{L}^{\prime}=$ Schiff base; $\mathrm{L}^{\prime \prime}=$ trisalicylidenetriethylenetetramine.

cal arrangement favors the ferromagnetic coupling between two metal centers [5f]. What's more, ferromagnetic coupling is rare for a face-shared $\mathrm{d}^{5}-\mathrm{d}^{5}$ system.

In light of numerous metal iron-citrate solution studies pertaining to charge, nuclearity, stoichiometry, $\mathrm{pH}$ dependability, stability, and relative concentration of species in aqueous solutions, 1-3 represent a typical and reasonable structural model for a dimeric iron-citrate species with general chemical features. However, the supramolecular networks of 1-3 are the first discussed in detail in this report on iron-citrate species. In the cases of the three iron(III) compounds, the uncoordinated protonated bpa, bpe and bpp cationic counterparts behave as donors. Variation of counter-cations in $\mathbf{1}\left(\mathrm{H}_{2} \mathrm{bpa}^{2+}\right), \mathbf{2}\left(\mathrm{H}_{2} \mathrm{bpe}^{2+}\right)$ and $\mathbf{3}$ $\left(\mathrm{H}_{2} \mathrm{bpp}^{+}\right)$not alter potentially and markedly to form the ring, but do influence the patterns of the interaction between the moieties to form the supramolecular networks. The magnetic data have stated the exoteric molecules hardly attributed to the anti-ferromagnetic exchange interactions between the two $\mathrm{Fe}(\mathrm{III})$ centers, the magneto-structural correlation may be impelled to the design of large spin ground state polynuclear complexes and molecular magnetic material in our future research.

\section{Acknowledgements}

We gratefully acknowledge financial support of this work by the National Natural Science Foundation of China (No. 20471048, TRAPOYT and SRFDP 20050697005).

\section{Appendix A. Supplementary material}

CCDC 627044, 627045 and 627046 contain the supplementary crystallographic data for $\mathbf{1}, \mathbf{2}$ and $\mathbf{3}$. These data can be obtained free of charge via http://www.ccdc.cam. ac.uk/conts/retrieving.html, or from the Cambridge Crystallographic Data Centre, 12 Union Road, Cambridge CB2 1EZ, UK; fax: (+44) 1223-336-033; or e-mail: deposit@ ccdc.cam.ac.uk. Supplementary data associated with this article can be found, in the online version, at doi: 10.1016/j.ica.2007.06.044.

\section{References}

[1] (a) P.A. Srere, Curr. Top. Cell. Regul. 5 (1972) 229; (b) J.P. Glusker, Acc. Chem. Res. 13 (1980) 345.

[2] (a) H.A. Krebs, W.A. Johnson, Enzymologia 4 (1937) 148; (b) H. Beinert, M.C. Kennedy, Eur. J. Biochem. 186 (1989) 5; (c) J. Liang, M. Madden, V.k. Shah, R.H. Burris, Biochemistry 29 (1990) 8577.

[3] (a) E.N. Baker, H.M. Baker, B.F. Anderson, R.D. Rreeves, Inorg. Chim. Acta 78 (1983) 282;

(b) B. Lonnerdal, A.G. Stanislowski, L.S. Hurley, J. Inorg. Biochem. 12 (1980) 71;

(c) C.D. Davis, J.L. Greger, Am. J. Clin. Nutr. 55 (1992) 747;

(d) T.H. Bothwell, R.D. Baynes, B.J. MacFarlene, A.P. MacPhail, J. Intern. Med. 226 (1989) 357.

[4] (a) A. Earnshaw, J. Lewis, J. Chem. Soc. 376 (1961);

(b) K.S. Marray, Coord. Chem. Rev. 12 (1974) 1.

[5] (a) M. Bobtelsky, J. Jordan, J. Am. Chem. Soc. 69 (1947) 2286;

(b) J. Strouse, S.W. Layten, C.E. Strouse, J. Am. Chem. Soc. 99 (1977) 562;

(c) M. Matzapetakis, C.P. Raptopoulou, J. Am. Chem. Soc. 120 (1998) 13266;

(d) A. Bino, S. Cohen, E.R. Bauminger, S.J. Lippard, Inorg. Chem. 37 (1998) 5168;

(e) I. Shweky, A. Bino, D.P. Goldberg, S.J. Lippard, Inorg. Chem. 33 (1994) 5161;

(f) X. Hao, Y.-G. Wei, S.-W. Zhang, Trans. Metal. Chem. 26 (2001) 384.

[6] (a) J.-M. Lehn, M. Mascal, A. Decian, J. Fischer, J. Chem. Soc., Perkin Trans. 2 (1992) 461;

(b) G.M. Whitesides, E.E. Simanek, J.P. Mathias, C.T. Seto, D.N. Chin, M. Mammen, D.M. Gordan, Acc. Chem. Res. 28 (1995) 37;

(c) J.A. Zerkowski, G.M. Whitesides, J. Am. Chem. Soc. 116 (1994) 4298 ;

(d) S. Banerjee, A.R. Choudhury, T.N. Guru Row, S. Chaudhuri, A. Ghosh, Polyhedron 26 (2007) 24;

(e) S.R. Batten, R. Robson, Angew. Chem. Int. Ed. 37 (1998) 1460; (f) D. Braga, F. Grepioni, V.R. Pedireddi, J. Am. Chem. Soc. 117 (1995) 31566; 
(g) G. Ferguson, P.I. Coupar, C. Glidewell, Acta Crystallogr., Sect B 53 (2005) 513.

[7] R.L. Carlin, Magnetochemistry, Spring-Verlag, Berlinibid, 1986, P3.

[8] G.M. Sheldrick, SHELXL-97: Program for Structure Determination and Refinement, University of Göttingen, Göttingen, 1997.

[9] (a) R. Swanson, W.H. Ilsley, A.G. Stanislowski, J. Inorg. Biochem. 18 (1983) 187 ;

(b) R.C. Bott, D.C. Sagatys, D.E. Lynch, T.C. Mark, Aust. J. Chem. 44 (1991) 1495;

(c) Z.-H. Zhou, Y -J. Lin, H.-B. Zhang, G.-D. Lin, K.-R. Tsai, J. Coord. Chem. 42 (1997) 131.

[10] N.S. Dean, M.R. Bond, C.J. O'Connor, C.J. Carrano, Inorg. Chem. 35 (1996) 7643.

[11] P. Koshits, M.A. Zh, Neorg. Khim. 13 (1968) 1233.

[12] (a) C.B. Aakeröy, K.R. Seddon, Chem. Soc. Rev. 22 (1993) 397;

(b) P. Gilli, V. Bertolasi, V. Ferretti, G. Gilli, J. Am. Chem. Soc. 116 (1994) 909.

[13] (a) M.C. Etter, Acc. Chem. Res. 23 (1990) 120;

(b) M.C. Rtter, J. Phys. Chem. 95 (1991) 4601;

(c) J. Bernstein, R.E. Davis, L. Shimoni, N.-L. Chang, Angew. Chem., Int. Ed. Engl. 34 (1995) 1555.

[14] (a) A. Bino, S. Cohen, E.R. Bauminger, S.J. Lippard, Inorg. Chem. 33 (1994) 5161;

(b) A. Bino, S. Cohen, E.R. Bauminger, S.J. Lippard, Inorg. Chem. 37 (1998) 5168.

[15] L. Carlucci, G. Ciani, D.M. Proserpio, S. Rizzato, CrystEng. Comm. 4 (2002) 121

[16] (a) J.B. Vincent, K. Folting, J.C. Huffman, Inorg. Chem. 25 (1986) 996; (b) H. Diril, H.-R. Chang, M.J. Nilges, X. Zhang, S.S. Isied, D.N. Hendrickson, J. Am. Chem. Soc. 111 (1989) 5102.

[17] M. Matzapetakis, N. Karligiano, A. Bino, J. Giapintzakis, A. Salifoglou, Inorg. Chem. 39 (2000) 4044.

[18] (a) C. Djordjevic, M. Lee, E. Sinn, Inorg. Chem. 28 (1989) 719; (b) G.B. Deacon, R.J. Philips, Coord. Chem. Rev. 33 (1980) 227.

[19] S.F. Triki, J.S. Bérézovsky, J.M. Clemente, P.A. Moline, Inorg. Chem. 39 (2000) 3771.
[20] O. Kahn, Molecular Magnetism, Wiley, VCH, New York, 1993.

[21] L. Yin, P. Cheng, X. Yao, H.-J. Wang, Chem. Soc., Dalton Trans. (1997) 2109.

[22] A.K. Boudalis, Y. Sanakis, C.P. Raptopoulou, V. Psycharis, Inorg. Chim. Acta 360 (2007) 39.

[23] V. Paredes-García, R.O. Latorre, E. Spodine, Polyhedron 23 (2004) 1869.

[24] (a) D.P. Goldberg, J. Telser, C.M. Bastos, S.J. Lippard, Inorg. Chem. 34 (1995) 3011;

(b) S. Dutta, R. Werner, S. Mohonta, K. Nag, Inorg. Chem. 35 (1996) 2292;

(c) A. Boudalis, N. Lalioti, G.A. Spyroulias, C.P. Raptopoulou, A. Terzis, V. Tangoulis, J.P. Tuchagues, S. Perlepes, Inorg. Chem. 41 (2002) 6474;

(d) B.T. Weldon, D.E. Wheeler, J.P. Kirby, J.K. McCusker, Inorg. Chem. 40 (2001) 6802;

(e) P. Kopel, M. Biler, Z. Trávnicek, M. Nádvorník, Acta Univ. Palackianae Olomucenesis. Chem. 37 (1998) 17;

(f) C. Wu, S.A. Hunt, P.K. Gantzel, G. Gütlich, D.N. Hendrickson, Inorg. Chem. 36 (1997) 4717.

[25] S.M. Gorun, S.J. Lippard, Inorg. Chem. 30 (1991) 1625.

[26] (a) J.A. Thich, C.C. Ou, D. Powers, B. Vasiliou, D. Mastropaolo, J.A. Potenza, H.J. Schugar, J. Am. Chem. Soc. 98 (1976) 1425;

(b) K, Wieghardt, Private communication;

(c) K.B. Jensen, C.J. Mckenzie, O. Simonsen, H. Toftlund, A. Hazell, Inorg. Chim. Acta 257 (1997) 163;

(d) B. Chiari, O. Piovesana, T. Tarantelli, P.F. Zanazzi, Inorg. Chem. 23 (1984) 3396;

(e) B. Chiari, O. Piovesana, T. Tarantelli, P.F. Zanazzi, Inorg. Chem. 21 (1982) 1396;

(f) H. Adams, N.A. Bailey, J.D. Crane, D.E. Fenton, J.-M. Latour, J.M. Williams, J. Chem. Soc., Dalron Tram. (1990) 1727; (g) B. Chiari, O. Piovesana, T. Tarantelli, P.F. Zanazzi, Inorg. Chem. 22 (1983) 2782.

[27] R. Hotzelmann, K. Wieghardt, U. Florke, J. Bonvoisin, J.J. Girerd, J. Am. Chem. Soc. 114 (1992) 1681. 